\title{
Phenotypic characterization of the Transylvanian wild boar population "Sus Scrofa Ferus"
}

\author{
Voichița Ana Maria GAVRILĂ, Crina Elena STRUGARIU, Teofil OROIAN * \\ Department of Fundamental Sciences, Faculty of Animal Science and Biotechnologies, University of \\ Agricultural Sciences and Veterinary Medicine, 3-5 Mănăștur Street, 400372 Cluj-Napoca, Romania \\ *corresponding author, e-mail: teoroian@yahoo.com
}

Bulletin UASVM Animal Science and Biotechnologies 73(1)/ 2016

Print ISSN 1843-5262; Electronic ISSN 1843-536X

DOI:10.15835/buasvmcn-asb: 11428

\begin{abstract}
:
This research study was based on requirements in the field of forestry in Transylvania, where there has been a decrease in the performance of conformation and constitution of the wild boar. In the studied area, we intend to monitor the phenotypic parameters: conformation and constitution of individuals by sex and age. The surveys were conducted over the years 2013-2014. The biological material was represented by 43 female and 63 male adults, aged over 3 years, harvested from three hunting grounds in Transylvania. Conformation measurements were made for the following characteristics: body length, height at the withers, croup height, thorax perimeter, body weight, head length, forehead width between the ears. Estimates were made of average and dispersion factors for each characteristics and phenotypic correlations were estimated between concerned characteristics. There is a large variability in all studied characteristics in both males and females, given by individual differences and higher performance limits for each characteristic, given by both individual variability, and environmental condition as well as harvesting season.
\end{abstract}

Key words: wild boar, body weight, height at the withers, height of the rump, height of the back

\section{INTRODUCTION}

The reviewed literature reveals little information on the phenotypic characterization of the wild boar. We share a few aspects and features of conformation and constitution reported by various authors. Hogs have compact body, a large head, and relatively short legs. Their fur is usually composed of rigid hair and softer fur. The colour usually varies from dark gray to black or brown, but there are big differences in colour from one region to another; e.g. whitish wild boars are known in Central Asia (Heptner et al. 2012). Adult boars can measure $90-200 \mathrm{~cm}$ in length, a tail of 15 to $40 \mathrm{~cm}$ and the waist height of $55-110 \mathrm{~cm}$ (Scheggi et al., 1999). Overall, their average weight is $50-90 \mathrm{~kg}$, though boars show greater variation in weight from one region to another.

Generally speaking, native Eurasian wild boars follow the Bergmann rule, with smaller pigs close to the tropics and higher in the northern part of their range. Mature sows in South Asia and South India may weigh less than $44 \mathrm{~kg}$.

In central Italy, their weight usually varies between $80-100 \mathrm{~kg}$, while boars shot in Tuscany have been found to weigh up to $150 \mathrm{~kg}$.

Amici (2010) confirms that different morph types of wild boar are detectable in some different areas of Central Italy. These morph types are differentiated on the basis of height and length measurements (head-body length, height at withers and hind-foot length); body weight can be relevant only for animals over three years of age.

Carpathian boars reached a record value of $200 \mathrm{~kg}$ in weight. Boars in Romania and Russia can reach weights of $300 \mathrm{~kg}$, while giants, unconfirmed in Russian hunting magazines, have been reported early weighing up to $320 \mathrm{~kg}$ (Scheggi et al., 1999).

The phenotype of wild Sus scrofa could thus be used as a basis to understand and possibly to control the invasive process that is responsible for the recent presence of these animals (Salvador, 
2014). Ethology and behavioural aspects for a boar were relevantly presented by Selaru (1995)

We have proposed monitoring phenotypic parameters of the wild boar population in Transylvania.

\section{MATERIAL AND METHODS}

The biological material consisted in 43 female and 63 male adults aged over 3 years, harvested from three hunting grounds in Transylvania. For each specimen, the data were collected individually, adding to the taken measurements biological samples for qualitative analysis of meat and DNA analysis. Samples were packaged, shipped and stored according to ANSVSA. The environmental factors of the regions (fields and mountains) had a major influence on data analysis. The data should be viewed in terms of correlation between soil, yield and density of wild boar $/ 100 \mathrm{Km}^{2}$, taking into consideration the types of crops and their diversity in the area. Estimates of the average and dispersion indices were made for each targeted specimen. The studied characteristics were: body length, height at the withers, rump height, thoracic perimeter, body weight, head length, head width between the ears. Based on phenotypic performances, phenotypic correlations between the characteristics were set using statistical formulas. Estimated correlations were made by combining the analysis of variables and covariance with Student test.

\section{RESULTS AND DISCUSSION}

Analysing averages and dispersion indices in harvested males aged over 3 years, with age fluctuations between 3 and 11 years old, we found that: the 43 analysed specimens have an average of $138.49 \pm 2.55 \mathrm{~cm}$ in body length, a lower value than the reports that show specimens over 6 years old of an average length around $178 \mathrm{~cm}$ (Oroian, 2012). By the same author, height at the withers in males averages at $96 \mathrm{~cm}$, while our research on a number of 43 random specimens shows an average of $82.30 \pm 1.67 \mathrm{~cm}$. The specific form is obvious in younger males, with the front part more developed than the back. The same fact is reflected in rump height with an average of 68.37 $\pm 1.76 \mathrm{~cm}$. The average thoracic perimeter in the analysed samples was $119.25 \pm 3.07 \mathrm{~cm}$ versus $138 \mathrm{~cm}$ communicated by the same author for younger males.

The average body weight of 43 individuals before gutting $102.13 \pm 3.90 \mathrm{~kg}$ is with a standard deviation of 25.56 and a uniformity coefficient of $25.03 \%$. The almost double value of the variation coefficient for this characteristic compared to the other analysed aspects confirms that the species' body weight is strongly influenced by the quality of the land and harvest period.

Average head length from the occipital crest to the tip of the snout is $46 \pm 0.96 \mathrm{~cm}$, with an average variation coefficient of $13.18 \%$. For this characteristic, the values communicated by Oroian (2012) are close. (Tab. 1)

Analysis of the average and dispersion indices in females older than 3 years (age is considered when the animal develops permanent teeth) indicates a body length of $144.11 \pm 2.31 \mathrm{~cm}$ and height at the withers and $78.94 \pm 1.27 \mathrm{~cm}$, measured on the 63 specimens. The coefficient of variation is average, between 12 and $13 \%$. For this characteristic, Oroian (2012) communicated an average of $160 \pm 3.93 \mathrm{~cm}$ and the shoulder height average of $90 \pm 0.3 \mathrm{~cm}$. Chest perimeter in these

Tab. 1 The average and dispersion indices of conformation characteristics in males over 3 years old

\begin{tabular}{lcccc}
\hline Specification & $\mathrm{n}$ & $\mathrm{X} \pm \mathrm{s}_{\mathrm{x}}$ & $\mathrm{S}$ & $\mathrm{V} \%$ \\
Body length $(\mathrm{cm})$ & 43 & $138.49 \pm 2.55$ & 16.70 & 12.05 \\
\hline Height at the withers & 43 & $82.30 \pm 1.67$ & 10.97 & 13.33 \\
\hline Height of the rump $(\mathrm{cm})$ & 43 & $68.37 \pm 1.76$ & 11.56 & 10.90 \\
\hline Height of the back $(\mathrm{cm})$ & 43 & $89.88 \pm 15.91$ & 10.77 & 14.54 \\
\hline Chest perimeter $(\mathrm{cm})$ & 43 & $119.25 \pm 3.07$ & 20.16 & 16.90 \\
\hline Body weight $(\mathrm{kg})$ & 43 & $102.13 \pm 3.90$ & 25.56 & 25.03 \\
\hline Head length $(\mathrm{cm})$ & 43 & $46 \pm 0.96$ & 6.52 & 13.18 \\
\hline Forehead width $(\mathrm{cm})$ & 43 & $15.72 \pm 0.60$ & 3.95 & 25.15 \\
\hline
\end{tabular}


females averages at $116.54 \pm 2.23 \mathrm{~cm}$, about 3.5 $\mathrm{cm}$ less than the values provided by Oroian (2012), where the average is $120 \pm 15 \mathrm{~cm}$. Due to the fact that most specimens were collected in December, January and February, the average body weight was $87.84 \pm 1.43 \mathrm{~kg}$, as compared to the weight of the same age category animals, harvested in August, September, October, which weighed, on average, $145 \pm 8.87 \mathrm{~kg}$ (Oroian,2012). The average length of the head for the 63 females analysed is $42.27 \pm 0.68 \mathrm{~cm}$, and the width of the forehead between ears is $13.60 \pm 0.22 \mathrm{~cm}$, slightly lower than the values communicated by Oroian (2012): $44 \pm 1.48 \mathrm{~cm}$, and $16 \pm 0.82 \mathrm{~cm}$, respectively.

Phenotypic correlations between the specimens were calculated to observe the meaning and the degree of interdependence between the values of the two characteristics. Correlations are specific to the traits estimated, which means that the values of correlation coefficients vary from one couple of characteristics to another, even within the same animal population. Phenotypic correlations are specific to each population they are estimated for, which means that the correlation values of same couple of characteristics differ from one population to another. Correlations are specific to the environmental condition in which the population lives. This causes the correlation coefficient between two characteristics to be different. Coefficient correlations range between -1 and +1 . By value or effect we may have positive or negative correlations. A close correlation of +1 or -1 means that the two studied characteristics are controlled by a set of common pleiotropic genes. Literature (Vlaic, 2004) specifies that in the interpretation of correlation results we should take into account the following: closely correlated characteristics when $r>0.5$, medium correlated characteristics when the correlation coefficient (r) is $0.2-0.5$, and poorly correlated characters when $\mathrm{r}<0.2$.

Between body length and height at the withers, croup height and height at the back of a male, the correlations are medium and positive, between 0.35 and 0.38 (Table 3). The population of females over three years old, for the same characteristics,

Tab. 2 The average and dispersion indices of conformation characteristics in females over 3 years old

\begin{tabular}{lcccc}
\hline Specifications & $\mathrm{n}$ & $\mathrm{X} \pm \mathrm{s}$ & $\mathrm{S}$ & $\mathrm{V} \%$ \\
Body length $(\mathrm{cm})$ & 63 & $144.11 \pm 2.31$ & 18.37 & 12.75 \\
\hline Height at the withers $(\mathrm{cm})$ & 63 & $78.94 \pm 1.27$ & 10.08 & 12.77 \\
\hline Height of the rump $(\mathrm{cm})$ & 63 & $65.87 \pm 1.07$ & 8.49 & 12.88 \\
\hline Height of the back $(\mathrm{cm})$ & 63 & $71.65 \pm 1.15$ & 9.17 & 12.79 \\
\hline Chest perimeter $(\mathrm{cm})$ & 63 & $116.54 \pm 2.23$ & 17.71 & 15.20 \\
\hline Body weight $(\mathrm{kg})$ & 63 & $87.84 \pm 1.43$ & 11.33 & 12.90 \\
\hline Head length $(\mathrm{cm})$ & 63 & $42.27 \pm 0.68$ & 5.40 & 12.78 \\
\hline Forehead width $(\mathrm{cm})$ & 63 & $13.60 \pm 0.22$ & 1.75 & 12.89 \\
\hline
\end{tabular}

Tab. 3 Phenotypic correlations for males aged over 3 years old

\begin{tabular}{lccccccc}
\hline Characteristics & $\begin{array}{c}\text { Height of } \\
\text { the withers }\end{array}$ & $\begin{array}{c}\text { Height of } \\
\text { the rumps }\end{array}$ & $\begin{array}{c}\text { Height of } \\
\text { the back }\end{array}$ & $\begin{array}{c}\text { Chest } \\
\text { perimeter }\end{array}$ & $\begin{array}{c}\text { Body } \\
\text { weight }\end{array}$ & $\begin{array}{c}\text { Head } \\
\text { length }\end{array}$ & $\begin{array}{c}\text { Forehead } \\
\text { width }\end{array}$ \\
\hline Body length & 0.38 & 0.38 & 0.35 & -0.17 & 0.32 & 0.29 & 0.11 \\
\hline Height of the withers & - & 0.74 & 0.90 & 0.46 & 0.64 & 0.24 & 0.04 \\
\hline Height of the rumps & - & - & 0.85 & 0.31 & 0.99 & 0.24 & 0.03 \\
\hline Height of the back & - & - & - & 0.46 & 0.66 & 0.31 & 0.06 \\
\hline Chest perimeter & - & - & - & - & 0.40 & 0.06 & 0.04 \\
\hline Body weight & - & - & - & - & - & 0.34 & 0.19 \\
\hline Head length & - & - & - & - & - & - & 0.29 \\
\hline Forehead width & - & - & - & - & - & - & - \\
\hline
\end{tabular}


Tab. 4 Phenotypic correlations for females aged over 3 years old

\begin{tabular}{|c|c|c|c|c|c|c|c|}
\hline Characteristics & $\begin{array}{l}\text { Height } \\
\text { of the } \\
\text { withers }\end{array}$ & $\begin{array}{l}\text { Height of } \\
\text { the rumps }\end{array}$ & $\begin{array}{l}\text { Height of } \\
\text { the back }\end{array}$ & $\begin{array}{c}\text { Chest } \\
\text { perimeter }\end{array}$ & $\begin{array}{c}\text { Body } \\
\text { weight }\end{array}$ & $\begin{array}{l}\text { Head } \\
\text { length }\end{array}$ & $\begin{array}{l}\text { Forehead } \\
\text { width }\end{array}$ \\
\hline Body length & 0.44 & 0.29 & 0.32 & 0.02 & 0.36 & -0.12 & -0.23 \\
\hline Height of the withers & - & 0.63 & 0.82 & 0.12 & 0.11 & 0.26 & 0.09 \\
\hline Height of the rumps & - & - & 0.80 & 0.12 & 0.01 & 0.41 & -0.03 \\
\hline Height of the back & - & - & - & 0.14 & 0.04 & 0.41 & 0.03 \\
\hline Chest perimeter & - & - & - & - & 0.24 & 0.22 & -0.02 \\
\hline Body weight & - & - & - & - & - & 0.06 & -0.07 \\
\hline Head length & - & - & - & - & - & - & 0.08 \\
\hline Forehead width & - & - & - & - & - & - & - \\
\hline
\end{tabular}

shows correlations with values between 0.29 and 0.44. (Table 4)

A strong and positive correlation is shown between male height at the withers and the characteristics: croup height, back height, body weight, with values between 0.64 and 0.90 . In females, positive and strong correlations are shown between height at withers to rump height 0.63 and height at withers to height of back 0.82 . Males had the averages of withers height and chest perimeter of 0.46 , and females had lower values of 0.12 . Between head length and breadth forehead correlation in males is in the middle limit 0.29, while females show a very low value of 0.08 (Tab. 3 and 4).

\section{CONCLUSIONS}

There is a large variability in all studied characteristics, in both males and females, given by individual differences and higher performance limits for each characteristic, given by individual variability, environmental conditions and harvesting season.

The body weight of wild boar cannot be considered as a selection criterion, due to its fluctuations depending on sex, climatic conditions and harvesting period.

Indicators that could be considered for a programme to improve the population could be: body length, rump height and back height.
Both in males and females, the highest correlations are between height at the withers and rump height, and height at the withers and back height.

The lowest correlations are between all the studied characteristics and forehead width.

For the first time in Romania, we did conformation measurements considering a split of wild boar populations in Transylvania, Apuseni mountains, based on sex and age.

\section{REFERENCES}

1. Amici A, Serrani F, Adriani S (2010). Somatic variability in wild boar (Sus scrofa L.) in different areas of Central Italy. Ital J Anim Sci 9(9): 39-44.

2. Vlaic Augustin, Teofil Oroian (2004). Elemente de genetică, Ed AcademicPress, Cluj Napoca ISBN 973-8266-43-2.

3. Cotta V, Bodea M, Micu I (2001). Vânatul și vânătoarea în România", Ed. Ceres, București

4. Oroian T, Oroian R, Pascalau S, Covrig I (2012). Mistreţul, umbra tăcută şi mister genetic al pădurilor românești. Ed. Risoprint Cluj-Napoca

5. Heptner VG, Sludskii AA (1989). Mammals of the Soviet Union Vol. II, Part 2 Ultimateungulate.com Retrieved on 2012-08-21

6. Salvador C, Fernandez FAS (2014). Using the Eurasian Wild Boar Phenotype as a Basis to Document a New Process of Invasion by Sus scrofa L. in a Neotropical Biodiversity Hotspot. Wildl Biol Pract 10 (3): 22-29.

7. Scheggi M. (1999). La BestiaNera: Caccia al Cinghialefra Mito, Storia e Attualita. Pp 201

8. Selaru, N. (1995). Mistreţul - monografie, Ed. Salut-2000, Bucureşti. 